\title{
Relationship among Iranian EFL Learners' Self- efficacy in Writing, Attitude towards Writing, Writing Apprehension and Writing Performance
}

\author{
Hoda Sarkhoush \\ English Department, Islamic Azad University of Shiraz, Iran
}

\begin{abstract}
The main trust of the present study was to investigate whether writing performance in students of English as a foreign language (EFL) was related to self-efficacy in writing, writing apprehension, and attitude towards writing. Fifty IELTS students (30 females and 20 males) studying IELTS Writing participated in this study. In order to collect data, three instruments were used which were a writing apprehension test (WAT), a self-efficacy in writing scale (SWS), and a questionnaire on attitude towards writing (WAQ). In order to make the questionnaires more comprehensible, they were adapted to Iranian context. This study conducted in two phases. First, the questionnaires were administered in the fist hour. In the second phase participants were given 45 minutes to write an argumentative essay on a given topic. The compositions were scored according to IELTS Writing Band Descriptive for public version by two raters. The obtained marks were taken to indicate the students' overall writing performance. The findings of the study suggested that, self-efficacy in writing and writing apprehension was negatively correlated. Moreover there was a positive correlation between selfefficacy and attitude towards writing. Besides, the results showed that self-efficacy and writing performance were positively correlated. The correlation between writing apprehension and attitude towards writing was negative. Finally there was a negative correlation between writing apprehension and writing performance. The results of a three-way ANOVA revealed that those learners with positive attitudes performed significantly better than those with negative attitudes on writing task. In terms of self-efficacy and apprehension levels no significant differences were found.
\end{abstract}

Index Terms - attitude towards writing, self-efficacy in writing, writing apprehension

\section{INTRODUCTION}

According to Celce-Murcia (1991), expressing one's feeling in a written form especially in a second or foreign language and doing it with acceptable coherence and cohesion is a great success.

Writing considerer as a complex task so the amount of anxiety level will be heightened in students who perform writing task. Sometimes this anxiety demotivates students and caused the negative attitude towards writing and their confidence (Gere, 1987; Sharples, 1993).

Over decades investigators have tried to find out practical solutions and approaches to enhance students writing. But regardless of the approaches and methods they used, students desire to show negative attitude towards writing. Not only ordinary students but also proficient students, those who are talented in other language skills such as speaking, reading, and listening, share the same problem in writing task. They always think it is beyond their capabilities to express themselves in written English.

Resent research findings compare the proficient writers and less skilled ones, it become obvious that those who performed better in writing tasks are more knowledgeable than their less skilled peers (Graham, 2006b; Graham \& Harris, 2005). For example Graham, et al. (1993) found that sophisticated writers were more likely to emphases on planning and revision strategies whereas unskilled writers concentrated on surface-level features of writing such as neatness and spelling writers. Olinghouse and Graham (2009) also found the differences between skilled and unskilled writers. In their studies, students were interviewed based on their writing performance experience and their ability to write. The results of the study showed older students not only were more knowledgeable about the characteristics of good writing, but also more knowledgeable about the writing process. It confirmed that knowledgeable writers considered two elements as the most important ones in their writing which were the role of effort and motivation for completing writing tasks.

Besides the differences found between skilled and unskilled writers Graham, et al. (1993) found another differences which were based on how skilled and unskilled writers understand the value and the purposes of writing.

Lin and colleagues (2007) found that more experienced writers concentrated on conveying meaning to the reader, whereas inexperience writers focused on the physical characteristics of writing task.

Series of studies showed that writing knowledge can be a predicator of writing performance (Benton, Corkill, Sharp, Downey, \& Khramtsova, 1995; Kellogg, 1987). In a study by Benton and colleagues (Benton \& Kiewra, 1986), students were asked to do some writing tasks such as unscramble letters, words, sentences, and paragraphs. They concluded 
that students with greater writing knowledge performed significantly better on writing task than participants with limited writing ability. The results of the studied also showed that sophisticated writers were more accurate and fluent.

Fidalgo and colleagues (Fidalgo, Torrance, \& Garcia, 2009) found similar results in their studies.

To the researchers' view three blockage psychological factors which are writing apprehension, self-efficacy in writing, and attitude towards writing considered as the most important ones in performing writing task. These factors are introduced and dealt with in the following sections.

\section{Writing Apprehension}

Writing apprehension is defined as "a psychological construct which is directly related to persons' tendencies or inclination to do or avoid a task that required writing accompanied by evaluation" (Dally 1978).

\section{Self-efficacy in Writing}

A person's self-efficacy defined as, "belief in one's capabilities to organize and execute the courses of action required producing given attainments" (Bandura, 1997, p. 3). How people act, think, and feel, directly reflected to their beliefs. So those who got high self-efficacy demonstrate high confidence and easily get involved in any activities. Whereas individuals with low self-efficacy and lack of confidence avoid any task and activities that surpass their capabilities (Bandura, 1977).

\section{Attitude towards Writing}

The feelings of writer about his or her writing refer to writing attitude which is mostly ranges from happy to unhappy (Graham, Berninger \& Fan, 2007). Writing attitude is not only the individuals' feeling ("I think my writing is good") but also the students' evaluation of their writing ("I think my instructor reacts positively to my writing").

\section{Theoretical Framework}

Anxiety as a dominant feature is reflected in highly apprehensive writers so they find writing unrewarding, even punishing. Consequently they avoid any possible situations that require writing (Daly \& Miller, 1975).Anxiety is reflected in the behaviors of apprehensive writers as they write, in the attitudes they express about their writing, and in their written products. Low apprehensive on the other hand, tend not to avoid situations that demand writing, so they display confidence in their abilities to write, and frequently enjoy writing.

On the other hand, significant bodies of studies clearly demonstrate that students' self-efficacy beliefs can be positively associated with academic achievements (Zimmerman, 1989; Zimmerman, Bandura, \& Martinez-Pons, 1992; Bandura, 1997; Pajares, 2002; Webb-Williams, 2006).

In addition, students who showed positive attitude towards writing are more eager to involve in writing task than their peers who hold negative attitude on the same task (McKenna, Kear, \& Ellsworth, 1995).

Objectives of the Study

This study intends to investigate whether writing performance in students of English as a foreign language (EFL) is related to self-efficacy in writing, writing apprehension, and attitude towards writing task. More specifically, the study seeks answers to the following questions:

1. Do individuals with low writing apprehension perform significantly better on a test of writing skills than those with high writing apprehension?

2. Do individuals with high self-efficacy perform significantly better on a test of writing skills than those with low self-efficacy?

3. Do students with positive attitudes towards writing perform better in writing tasks than those with negative attitudes?

4. Is there a relationship among self-efficacy in writing, attitude towards writing, writing apprehension and writing performance?

\section{Research on Apprehension and Writing Performance}

Hassan (2001) investigated the relationship between self-esteem in writing and writing apprehension. 182 university students were participated in this study. In order to assess students apprehension and self-efficacy two questionnaires were given to students which were foreign language self-esteem questionnaire and writing apprehension questionnaire. Students also ask to write a composition. The results of the study confirmed that:

1. There was a significant relationship between self-esteem and writing apprehension. High apprehensive writers suffer from lower self-esteem than their peers with low apprehension.

2. Low apprehensive writers wrote better than high apprehensive writers.

Pajares and Johnson (1994) said that writing apprehension is negatively correlated with self-efficacy. These findings supported the fact that writing capability can directly predict writing performance (Pajares \& Valiante's, 1996)

\section{Research on Self-Efficacy and Writing Performance}

McCarthy, Meir and Rinderer (1985), and Pajares and Johnson (1996) have found that there was a relationship low level of self-efficacy and poor writing. They found that those students, who evaluated themselves to be talented writers, would write well, whilst the students who considered themselves to be poor writers, would perform according to their beliefs.

Bandura (1997), Beach (1989), Meier, McCarthy, and Schmeck, (1984), Shell, Murphy and Bruning (1989), McCarthy, Meier and Rinderer (1985), and McCarthy, Meier, and Rinderer, (1985) have all also stated that academic 
self-beliefs are strongly predictive of academic performance. They considered self-efficacy as the key elements in writing performance.

Graham and colleagues (2007) investigated the relationship between writing attitude and writing performance. The results of the study revealed that those students who had positive writing attitude got better achievement in writing task than those with less favorable attitude towards task. In a similar study Graham, et al. (2007) also found that writing attitudes can be a significant predicator of writing achievement.

\section{Methodology}

\section{Participants}

Fifty IELTS students (30 females and 20 males) studying IELTS Writing participated in this study. All the students were native speakers of Persian. The participants were given 3 questionnaires, a self-efficacy in writing scale (SWS), a writing apprehension test (WAT), and a questionnaire on attitude towards writing (WAQ). On the basis of the results, they were classified into high and low levels. Table 1 shows the distribution of the participants according to the variables levels.

TABLE 1:

DistRIBUTION OF PARTICIPANTS ACCORDING TO THE VARIABLES

\begin{tabular}{|ll|l|l|}
\hline & Value Label & N \\
\hline attitude level & 1 & negative & 23 \\
Self-efficacy level & 2 & positive & 24 \\
& 1 & low & 22 \\
Apprehension level & 2 & high & 23 \\
& 1 & low & 22 \\
& 2 & high & 25 \\
\hline
\end{tabular}

\section{Instruments}

The instruments in the study were modified versions of: A self-efficacy in writing scale (SWS), A writing apprehension test (WAT), and an attitude-towards-writing questionnaire (WAQ). In order to grade the students' writing, IELTS Writing Band Descriptor for public version was used.

\section{Issues of Reliability and Validity}

\section{- Writing Apprehension Questionnaire}

For this study, we used Daly and Miller's (1975a) WAT to evaluate students' apprehension on writing. This is a 26item questionnaire that features 13 items with positive polarity and 13 with negative polarity. Those items which were reversed were recorded to the same variables in data analysis. Scoring was done on a 5-point Likert scale that asked the participants to state whether they agreed or disagreed with the statements about writing apprehension.

In order to calculate the reliability of the WAT Cronbach's Alpha reliability coefficient was used. The result showed that the reliability of the instrument was 0.89 (Table 2).

TABLE 2:

RELIABILITY OF WAT

\begin{tabular}{|c|c|}
\hline Cronbach's Alpha & $\mathrm{N}$ of Items \\
\hline .891 & 26 \\
\hline
\end{tabular}

\section{- Self-Efficacy in Writing Scale (SWS)}

In order to assess students' self-efficacy in writing we used Yavuz-Erkan (2004) self-efficacy scale in writing. Yavuz-Erkan developed a 21-item writing self-efficacy scale to grade the strength of students' belief in their writing ability. The scoring was done on 5-point Likert scale: Strongly Disagree, Disagree, Agree, or Strongly Agree. Each statement on the scale was preceded by the phrase "I can ..."

Five factors which were content, design, unity, accuracy and punctuation were considered in this questionnaire.

The reliability was calculated. The scale was found to have Cronbach's Alpha reliability coefficient of 0.90 (Table 3).

TABLE 3:

RELIABILITY OF SWS

\begin{tabular}{|l|l|}
\hline Cronbach's Alpha & N of Items \\
\hline .900 & 28 \\
\hline
\end{tabular}




\section{- Attitudes toward Writing Questionnaire (WAQ)}

Rose's (1984) attitude-towards-writing questionnaire (WAQ) was the third measurements that used in this study. This questionnaire tries to examine the link between attitude towards writing and the students' actual writing performances. It consists of 24 items. The items of the scale were in Likert scale: Almost Always, Often, Sometimes, Occasionally, or Almost Never. This questionnaire was also adapted to Iranian context the same as other instruments.

The reliability of WAQ was calculated through Cronbach's Alpha reliability coefficient and the result showed that the reliability of the instrument was 0.83 (Table 4).

TABLE 4:

RELIABILITY OF WAQ

\begin{tabular}{|l|l|}
\hline Cronbach's Alpha & N of Items \\
\hline 830 & 24 \\
\hline
\end{tabular}

Since the questionnaires were basically developed with reference to first-language learners, particularly English native speakers, and therefore may not tap the essential aspects of EFL context, the researcher adapted the WAT for use with Iranian EFL students as follows:

First, WAT, SWS, and WAQ were translated into Persian by three EFL instructors. Second, the translations were compared and necessary changes were made so that all items in the scales were comprehensible to Iranian EFL students. Then the scales were read by two Iranian lecturers. They were revised based on their comments and then they were administered to $5 \mathrm{EFL}$ students. After that the final version of the scales were established with feedback from the students' and lecturers' comments. Once in their final Iranian form, the scales were back-translated. The Iranian versions were translated into English to ensure a true translation. Then the team discussed any discrepancies until all members reached a consensus. The final versions turned out to be very similar to the original ones. Thus, the Persian versions were administered to the participants.

\section{Data Collection Procedures}

This study was conducted in two phases. WAT, WAQ, and WSQ were administered in the first session. Participants were informed that the purpose of the study was to investigate the effects of three psychological constructs apprehension, attitude, and self-efficacy on their writing ability. They were also informed that they would remain anonymous. In the second phase, students were given 45 minutes to write an argumentative essay entitled "Some people believe that there should be fixed punishments for each type of crime. Others, however, argue that circumstances of an individual crime, and the motivation for committing it, should always be taken into account when deciding on the punishment". To ensure that the students would view the performance task as serious, their professor informed them that the scores would be considered as part of their ongoing term grade.

The compositions were graded according to IELTS Writing Band Descriptors for public version by two raters. Both raters were English IELTS Instructors and they were unaware of the students' identification. In this part the inter-rater reliability was estimated to see how consistent the raters were in their judgments. To this end, Pearson Product Moment Correlation was used and then the obtained correlation coefficient was put in the inter-rater reliability formula (Henning 1987, p. 82).The Correlation Coefficient was 0.89 with p-value of 0.000 using Spearman Brown Prophecy formula (Henning 1987, p. 82), the inter-rater reliability was found to be 0.94 . The obtained marks were taken to indicate students' overall writing performance. The average of raters' scores was taken as the main scores for computation. Based on the results, the participants were divided into two groups of high and low ability in writing.

\section{Data Analysis Procedures}

Our data consisted of the results of the questionnaires--writing apprehension test, self-efficacy in writing, and attitudes towards writing -- on the one hand, and the score of the essay writing task on the other hand. The data gathered from the questionnaires and essay writing were entered into the computer item by item according to their own values, using the Statistical Package for Social Sciences (SPSS) Version 16 to get descriptive analysis, correlation analysis, and three-way ANOVA.

To determine the relationship among self-efficacy in writing, attitudes towards writing, writing apprehension and writing performance irrespective of sex and proficiency level was measured using Pearson Product Moment correlation. The individuals were divided into two groups and for this end; the median was calculated for each variable. The median for attitude was 71, for self-efficacy 68.5 , and for apprehension 90.5. In order to divide the students into two groups, each variable was recoded. Students who scored lower than the median got value 1, which indicated low self-efficacy, low apprehension, and negative attitude towards writing. Those who scored above the median got value 2, and were considered as having higher self-efficacy in writing, higher apprehension in writing, and positive attitude towards writing. Since there were three independent variables, a three-way ANOVA was run to find the significant differences among the groups. The analyses were carried out at a significance level of $\mathrm{p}<.05$

\section{FINDINGS AND DISCUSSION}


One of the aims of the present study was to determine the possible relationship among self-efficacy in writing, attitude towards writing, writing apprehension and writing performance. A correlation analysis was run and the results are summed up in Table5.

TABLE5:

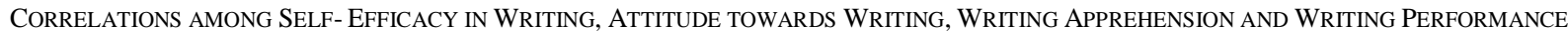

\begin{tabular}{|ll|l|l|l|}
\hline & & Self-efficacy & Apprehension & Writing \\
\hline Attitude & Pearson Correlation & $.606^{* *}$ & $-.469^{* *}$ & $.623^{* *}$ \\
& Sig. (2-tailed) & .000 & .001 & .000 \\
& $\mathrm{~N}$ & 50 & 50 & 50 \\
\hline Self-efficacy & Pearson Correlation & & $-.729^{* *}$ & $.513^{* *}$ \\
& Sig. (2-tailed) & & .000 & .000 \\
& $\mathrm{~N}$ & & 50 & 50 \\
\hline Apprehension & Pearson Correlation & & & $-.545^{* *}$ \\
& Sig. (2-tailed) & & & .000 \\
& $\mathrm{~N}$ & & & 50 \\
\hline
\end{tabular}

According to the results which appear in (Table 5)the Pearson correlation coefficient for attitude towards writing and self-efficacy in writing indicated a positive relationship between these two variables $\left(\mathrm{r}_{=.} 606, \mathrm{p}<.05\right)$ which means that high self efficacy is associated with high attitude towards writing. The Pearson correlation coefficient for attitude towards writing and apprehension in writing was $-.469,(\mathrm{p}<.05)$ indicating a negative relationship between apprehension in writing and attitude towards writing. The correlation between attitude and writing performance was also positive $\left(\mathrm{r}_{=} .623, \mathrm{p}<.05\right)$. It indicated that those with positive attitudes in writing would significantly perform better than those with negative attitudes.

According to the results, there was a negative relationship between self-efficacy and apprehension at the .000 level of significant. This means that higher self-efficacy is associated with the lower apprehension and a positive correlation between self-efficacy and writing performance $\left(\mathrm{r}_{=} .513, \mathrm{p}<.05\right)$. It means that those with high self-efficacy significantly perform better on the test than those with low self-efficacy. The correlation coefficient for writing apprehension and writing performance was negative $\left(\mathrm{r}_{=}-.545, \mathrm{p}<.05\right)$. It indicated that the students with high apprehension would perform weakly on their writing task.

Furthermore, a three-way ANOVA was run to assess the differences among the groups in terms of the levels of attitude towards writing, self efficacy in writing, and writing apprehension as independent variables and writing performance as the dependent variable. As the table of ANOVA shows (Table7), only attitude level is significant and there is a significant interaction between attitude level and apprehension level.

TABLE 7:

ANOVA RESUlTS ON THE EFFECTS OF ATTITUDE LEVEL, APPREHENSION LEVEL, AND SELF - EFFICACY LEVEL ON WRITING.

\begin{tabular}{|c|c|c|c|c|c|}
\hline Source & $\begin{array}{l}\text { Type III Sum of } \\
\text { Squares }\end{array}$ & Df & Mean Square & $\mathrm{F}$ & sig. \\
\hline Corrected Model & $15.838^{\mathrm{a}}$ & 17 & 2.263 & 4.329 & .002 \\
\hline Intercept & 895.725 & 1 & 895.725 & 1713.874 & .000 \\
\hline Alevel & 2.782 & 1 & 2.782 & 5.323 & .028 \\
\hline Slevel & .138 & 1 & .138 & .263 & .612 \\
\hline Aplevel & 1.481 & 1 & 1.481 & 2.833 & .102 \\
\hline Alevel * Slevel & .653 & 1 & .653 & 1.249 & .272 \\
\hline Alevel * Aplevel & 1.188 & 1 & 1.188 & 2.273 & .141 \\
\hline Slevel * Aplevel & 3.607 & 1 & 3.607 & 6.901 & .013 \\
\hline Alevel * Slevel * Aplevel & .234 & 1 & .234 & .447 & .508 \\
\hline Error & 16.724 & 32 & .523 & & \\
\hline Total & 1270.219 & 40 & & & \\
\hline Corrected Total & 32.563 & 39 & & & \\
\hline
\end{tabular}

Alevel=attitude level Aplevel=apprehension level Slevel=self-efficacy level

As can be seen from Table 8 , the mean of the group with positive attitude is higher than that of the group with negative attitude. It can be concluded that those with positive attitude towards writing perform better than those with negative attitude. 
TABLE 8:

DESCRIPTIVE STATISTICS ON WRITING BASED ON ATTITUDE LEVELS ${ }^{\text {A }}$

\begin{tabular}{|l|l|l|l|l|l|}
\hline \multicolumn{2}{|c|}{ DESCRIPTIVE STATISTICS ON WRITING BASED ON ATTITUDE LEVELS } \\
\hline & $\mathrm{N}$ & Minimum & Maximum & Mean & Std. Deviation \\
\hline Negative & 19 & 3 & 6 & 5.08 & .796 \\
Positive & 21 & 4 & 7 & 6.00 & .796 \\
\hline
\end{tabular}

According to ANOVA results, no significant differences were found in terms of the effect of self-efficacy and apprehension levels on writing performance.

\section{CONCLUSION}

Based on the procedure of the research, the participants for each variable--self-efficacy in writing, apprehension in writing, and attitude towards writing, were divided into two groups. Each group performed differently on questionnaires and writing task. The results of a three-way ANOVA revealed that those learners with positive attitudes performed significantly better than those with negative attitude. In terms of self- efficacy and apprehension levels no significant differences were found.

Correlation between variables demonstrated some results. According to the findings, self-efficacy in writing and writing apprehension are negatively correlated $(\mathrm{r}=-.729)$. On the other hand, there was a positive correlation between self-efficacy and attitude towards writing $(\mathrm{r}=.606, \mathrm{p}<.05)$. Moreover, the results showed that self- efficacy and writing performance were also positively correlated $(\mathrm{r}=.513, \mathrm{p}<.05)$.

The correlation between writing apprehension and attitude towards writing was negative( $r=-.469, \mathrm{p}<.05)$. Finally there was a negative correlation between writing apprehension and writing performance $(r=-.545, \mathrm{p}<.05)$.

\section{Pedagogical Implications of the Study}

Cognitive and emotional activities can deeply effects writing performance; so it is a need to nurture the affective aspects of EFL learning. Although our finding were not in line with other studies in terms of self-efficacy in writing and writing apprehension but to the researchers' view they could consider as blockage factors that may hinder the actual performance of the writers.

It is a need for EFL students to be aware of their capabilities, their attitudes, and their feeling. They should try to minimize the effects of the blockage factors. Moreover EFL instructors can guide to build students self-efficacy. They could enhance students' positive evaluation of their ability.

In a nut shell, writing always considers as a personal act, so that students' writing efficacy beliefs are easily vulnerable to any harsh criticisms. (Zumbrunn, et al., 2010). Although harsh criticisms can easily put students' efficacy beliefs in danger, ample praises can easily boost students' effort and persistence in writing tasks and cause them feel more efficacious.

\section{REFERENCES}

[1] Bandura, A. (1977). Self-efficacy: Toward a unifying theory of behavioral change. Psychological Review, 84(2), 191-215.

[2] Bandura, A. (1997). Self-efficacy: The exercise of control. New York: WH Freeman and Company.

[3] Beach, R. (1989). Showing students how to assess: Demonstrating techniques for response in the writing conference. In C.M. Anson (Ed.), Writing and Response (pp. 1277148).Urbana, IL: NCTE.

[4] Benton, S. L., \& Kiewra, K. A. (1986).Measuring the organizational aspects of writing ability. Journal of Educational Measurement, 23(4), 377-386.

[5] Benton, S. L., Corkill, A. J., Sharp, J. M., Downey, R. G., \& Khramtsova, I. (1995). Knowledge, interest, and narrative writing. Journal of Educational Psychology, 87(1), 66-79.

[6] Celce-Murcia, M. (1991). Language teaching methodology. London: Prentice Hall

[7] Daly, J. (1978). Writing apprehension and writing competency. Journal of Education Research, 72(1), 10-14.

[8] Daly J. and Miller, M. D. (1975). Apprehension of writing as a predictor of message intensity. The Journal of Psychology, 89, 173-177.

[9] Fidalgo, R., Torrance, M., \& Garcia, J. (2009).The long-term effects of writing strategy instruction for young writers. Contemporary Educational Psychology, 32(4), 516-536.

[10] Lin, S. C., Monroe, B. W., \& Troia, G. A. (2007). Development of writing knowledge in grades2-8: A comparison of typically developing writers and their struggling peers. Reading and Writing Quarterly, 23(3), 207-230.

[11] Gere, A. R. (1987). Writing groups: History, theory and implications. Carbondale: Southern Illionis University Press.

[12] Graham, S., Schwartz, S., \& MacArthur, C. (1993). Knowledge of writing and the composing process, attitude toward writing, and self-efficacy for students with and without learning disabilities. Journal of Learning Disabilities, 26(4), 237-249.

[13] Graham, S., Harris, K. R. (2005).Improving the writing performance, knowledge, and self-efficacy of struggling young writers: The effects of self regulated strategy development. Contemporary Educational Psychology, 30(2), 207-241.

[14] Graham, S. (2006). P. Alexander \& P. Winne (Eds.), Handbook of Educational Psychology (pp. 457-478). Mahwah, NJ: Erlbaum.

[15] Graham, S., Berninger, V., \& Fan, W. (2007).The structural relationship between writing attitude and writing achievement in first and third grade students. Contemporary Educational Psychology, 32(3), 516-536.

[16] Hassan, B. (2001). The relationship of writing apprehension and self-efficacy to the writing quality and quantity of EFL university student. Mansoura Faculty of Education journal, 39:1-6. 
[17] McCarthy, P., Meier, S., \& Rinderer, R. (1985). 'Self-Efficacy and writing: A different view of self-evaluation. College Composition and Communication, 36(4), 465-471.

[18] McCutchen, D. (1987). Children's discourse skill: Form and modality requirements of schooled writing. Discourse Processes, $10(3), 267-286$.

[19] McKenna, M. C., Kear, D. J., \& Ellsworth, R. A. (1995). Children's attitudes toward reading: A national survey. Reading Research Quarterly, 30(4), 934-956.

[20] Meier, S., McCarthy, P. R., \& Schmeck, R. R. (1984).Validity of self-efficacy as a predictor of writing performance. Cognitive Therapy and Research, 8(2), 107-120.

[21] Olinghouse, N. G., \& Graham, S. (2009). The relationship between the discourse knowledge and the writing performance of elementary-grade students. Journal of Educational Psychology, 101(1), 37-50.

[22] Pajares, F., \& Johnson, M. J. (1994). Confidence and competence in writing: The role of writing self-efficacy, outcome expectancy, and apprehension. Research in the Teaching of English, 28(3), 313-331.

[23] Pajares, F. (2002). Overview of social cognitive theory and of self-efficacy. Retrieved December 11, 2011, from http://www.emory.edu/EDUCATION/mfp/eff.html.

[24] Pajares, F., \& Johnson, M. (1996).Self-efficacy beliefs and the writing performance of entering high school students. Psychology in the Schools, 33(2), 163-175.

[25] Rose, M. (1984).Writer's block: The cognitive dimension. Carbondale, IL: Southern Illionis University Press

[26] Saddler, B., \& Graham, S. (2007). The relationship between writing knowledge and writing performance among more and less skilled writers. Reading \& Writing Quarterly: Overcoming Learning Difficulties, 23(3), 231-247.

[27] Sharples, M. (Ed.) (1993).Computer supported collaborative writing. Spring: Verlag.

[28] Shell, D. F., Murphy, C. C., \& Bruning, R. H. (1989).Self-efficacy and outcome expectancy mechanisms in reading and writing achievement. Journal of Educational Psychology, 81(1), 91-100.

[29] Webb-Williams, Jane. (2006). Self-efficacy in the primary classroom: An investigation into the relationship with performance. Paper presented at the British Educational Research Association New Researchers/Student Conference, University of Warwick, Britain.

[30] Yavuz-Erkan, D. (2004). Efficacy of cross-cultural e-mail exchange for enhancing EFL writing: Unpublished Dissertation Abstract. lukurova University, The Institute of Social Sciences English Language Teaching. Adana/Turkey.

[31] Zumbrunn, S., Bruning, R., Kauffman, D., \& Hayes, M. (2010).Explaining determinants of confidence and success in the elementary writing classroom. Paper presented at the annual meeting of the American Educational Research Association, Denver, CO.

[32] Zimmerman, B. J. (1989). A social cognitive view of self-regulated academic learning. Journal of Educational Psychology, 81(3), 329-339.

[33] Zimmerman, B. J., Bandura, A. \& Martinez-Pons, M. (1992).Self motivation for academic attainment: The role of self-efficacy beliefs and personal goal setting. American Educational Research Journal, 29 (20), 663-676.

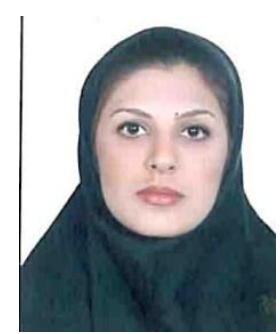

Hoda Sarkhoush got her M.A. in TEFEL (Teaching English as a Foreign Language) in Shiraz Azad University, Fars, Iran in 0ctober 2012. She was born in Shiraz.

She is an English teacher. She teaches English for more than 9 years.

Miss Hoda Sarkhoush has not been the member of any professional societies. 